\title{
PERFORMANCE OF BROILER CHICKEN FED VARIED NUTRIENT DENSITY DIETS SUPPLEMENTED WITH DIRECT FED MICROBIAL
}

\author{
KATOCH S*, SHARMA KA*, CHAHOTA R*, SHARMA KS*, MARKOVIĆ RADMILA**, ŠEFER D** \\ *Himachal Pradesh Agriculture University, DGCN College of Veterinary and Animal Sciences \\ CSK, Palampur, India; \\ **University of Belgrade, Faculty of Veterinary Medicine, Belgrade, Serbia
}

(Received $14^{\text {th }}$ February 2013)

Comparative dietary response of different isolated strains (Direct fed microbial- DFM) of lactobacilli, streptococci and yeast isolated from leopard feces (Panthera leo) was studied as probiotic in poultry broiler birds reared as per varied mineral densities viz. calcium and phosphorus. Various treatments consisted of TO (Control, culture medium), T1 (Lactobacillus casei + Streptococcus fecalis + Saccharomyces cerevisiae) offered standard formulated diet D1, T2 - Control (Culture medium) offered ten percent lower calcium and phosphorus diet D2, T3 (Lactobacillus casei + Streptococcus fecalis + Saccharomyces cerevisiae) offered ten percent lower calcium and phosphorus diet D2. Growth results obtained during the starter phase $\left(1^{\text {st }}\right.$ to $3^{\text {rd }}$ week) exhibited higher gain in live body weight and lower feed conversion ratio, both by DFM supplemented treatment T1 offered standard formulated diet $D 1$ and treatment $T 3$ offered experimentally formulated mineral ( $\mathrm{Ca}$ and $\mathrm{P}$ ) deficient (10\%) diet D2 compared to respective control TO and T2. The obtained results revealed a significantly higher growth performance in treatment $T 1$ compared to its control TO where a higher growth in treatment T3 offered experimentally formulated mineral (Ca and P) deficient (10\%) diet D2 supplemented with isolated DFM compared to its control T2 was exhibited. Treatment groups T1 and T3 supplemented with isolated DFM exhibited a better intestinal micro flora balance, effective colonization and higher count in the intestinal tract with higher calcium and phosphorus retention in the digestibility studies. Thus, it was found that supplementation of isolated DFM has the potential to improve biological growth performance of poultry broiler birds offered both standard formulated diet D1, as well as mineral deficient diet $D 2$.

Key words: broiler, calcium, feed, microbes, phosphorus, probiotics 


\section{INTRODUCTION}

Economic poultry production envisages the use of nutritionally wellbalanced feeding and better feed efficiency. Digestive efficiency in chicken can be enhanced by incorporating suitable additives to their diets, like growth promoters, enzymes and probiotics. The use of direct fed microbial and other nontraditional feed additives has increased in response to demands for using more "natural" growth promoting substances. Probiotics or direct fed microbial are slowly gaining importance and are being accepted for use as alternative feed additives to reduce the cost of production in poultry production. Proper balance of micro organisms is an important feature of a well functioning gastrointestinal tract and a healthy intestine is dominated by lactic acid producing bacteria. This balance is disturbed by stress, disease or antibiotic treatment (Lyons, 1987). Lactobacilli, Streptococci, Bifidobacterium and Yeast i.e. accharomyces are the most commonly used groups of microbes in the production of probiotics/ DFM. The justification for the use of lactobacilli originates from the results, that gut micro flora develops after birth, as the lactobacilli increased, other populations of the flora decreased (Smith, 1965). Yeasts, unicellular fungi, are also known for their fermentative ability. They produce enzymes such as amylases, proteases, lipases, celluloses as well as B-complex vitamins in the medium in which they grow. In addition yeasts have a buffering effect in the digestive tract by mediating a sharp decrease of $\mathrm{pH}$. Probiotics keep the gut at a desirable $\mathrm{pH}$ thus allowing the growth of beneficial bacteria which produce natural antibiotic like substances called bacteriocins (Suskovic et al., 1997) which help to eliminate unwanted coli forms. The main benefits of feeding probiotics to poultry include stimulation of the immune system (Sanders, 1984), improved utilization of proteins, improved intestinal tract health (Sitonen et al., 1990, Isolauri et al. 1991 and Seki et al. 1978) reported that an increased feed conversion ratio results in increased beneficial microbial population and suppression of harmful bacterial growth in the digestive system. It also counteracts ill effects of antibiotic treatment by sustaining the population of beneficial bacteria and helps in nutrient synthesis and increases its bioavailability (Shahani et al., 1971).

During stress or use of anti bacterials, the $\mathrm{pH}$ of the small intestines rises thus allowing the growth of harmful bacteria to take a foot-hold in the lining of the intestines due to the deterioration of the protective mucus lining, as a result of which intestinal villi can be damaged which ultimately will inhibit nutrient absorption. Increasing beneficial gut micro flora through the use of probiotic/ DFM will compete against harmful bacteria and decrease the $\mathrm{pH}$ of the environment thus enhancing nutrient absorption and preventing infection (Topping, 1996). The research was therefore carried out with the objective to study the biological performance of broiler chicken offered varied density nutrient diets supplemented with isolated direct fed microbials (DFM). 


\section{MATERIAL AND METHODS}

One week- old, 160 broiler chicks of strain Van Cobb were divided at random in four treatments in 8 compartments of battery brooders having 40 chicks in each treatment with two replicates of 20 chicks each. Experimental plan comprised of 4 treatments i.e. T0: Control (Culture medium) offered standard formulated diet D1 (Table 1) as per NRC recommendation (1994); treatment T1- offered standard formulated diet D1 and combination of isolated DFM namely Lactobacillus casei $(6.8 \times 108$ cells cfu/ kg feed + Streptococcus faecalis $(6.8 \times 108$ cells cfu/ kg feed, + Commercial Yeast (Food grade) Saccharomyces cerevisiae (5.8 x 107 $\mathrm{cfu} / \mathrm{kg}$ feed); T2- Control (culture medium) offered experimentally formulated varied mineral density test diet D2 (Table 1) having 10 per cent lower calcium and phosphorus then standard formulated diet D1; treatment T3 offered an experimentally formulated varied mineral density test diet D2 (Table 1) and a combination of isolated DFM namely Lactobacillus casei $(6.8 \times 108$ cells cfu/kg feed + Streptococcus faecalis $(6.8 \times 108$ cells cfu/kg feed, + Commercial Yeast (Food grade) Saccharomyces cerevisiae (5.8 x $107 \mathrm{cfu} / \mathrm{kg}$ feed).

Formulation of Diets: Standard broiler starter and finisher diet was a corn-soybean-fishmeal based diet that met or exceeded all National Research Council (1994) nutrient recommendations (Table 1) and the dietary test treatment consisted of 2 levels of isolated DFM $(0$ and $6.8 \times 108+6.8 \times 108+5.8 \times 107$ cells $/ \mathrm{mL}$ ) and 2 nutrient densities (D1 \& D2) which differed in their calcium and phosphorus contents. The control/ standard formulated diet D1 was formulated to meet or exceed National Research council (1994) recommendations for Ca and $\mathrm{P}$ where experimental test diet D2 was formulated to be 10 per cent lower in calcium and phosphorus compared with the control standard diet D1 both in starter and finisher formulations.

Management and recording of observations: Different microbial cultures (1 $\mathrm{mL}$ diluted with $100 \mathrm{~mL}$ distilled water) as per experimental plan were mixed with feed quota of a particular treatment before everyday feeding and it was continued during the entire period of the feeding trial. To prevent cross contamination of supplemented DFM, dietary assignments to cages were not completely random. Instead, cages and battery arrangements were carefully selected to ensure that: 1) each diet was represented in each level of a battery; 2) there was enough sideways separation to prevent feed or water from cross contamination. In addition, management of the birds ensured that birds without DFM were offered feed first. Whenever possible, separate workers were used to reduce cross contamination. Standard management practice was followed for rearing and parameters like gain in weight (GIW), feed consumption, feed conversion ratio (FCR), dressing percent and mortality percent were recorded on regular basis. At the end of the starter phase, a digestibility trial was conducted for a period of five days. All the experimental broilers were sacrificed after completion of the trial to record dressing percentage, total and differential microbial counts in the caecum and gastro intestinal tract (Baba et al., 
1991). Calcium was estimated by Atomic Absorption Spectro-photometry (Perkin Elmer, 1982), while phosphorus was estimated by the method proposed by Parks and Dunn (1963).

Table 1. Ingredients and nutrient contents of experimental diets

\begin{tabular}{|c|c|c|c|c|}
\hline & \multicolumn{2}{|c|}{ Starter (1-28d) } & \multicolumn{2}{|c|}{ Finisher (28 to $42 \mathrm{~d}$ ) } \\
\hline $\begin{array}{l}\text { Ingredients } \\
\text { (parts } / 100 \mathrm{~kg} \text { ) }\end{array}$ & $\begin{array}{c}\text { Nutrient level } \\
\text { D1* }\end{array}$ & $\begin{array}{c}\text { Nutrient level } \\
\text { D2** }\end{array}$ & $\begin{array}{c}\text { Nutrient level } \\
\text { D1* }\end{array}$ & $\begin{array}{c}\text { Nutrient level } \\
\text { D2 }\end{array}$ \\
\hline Maize & 35 & 35 & 44 & 44 \\
\hline $\begin{array}{l}\text { Groundnut Cake } \\
\text { extract (Solvent) }\end{array}$ & 26 & 26 & 24.3 & 24.3 \\
\hline Whole Soyabean & 24 & 24 & 17 & 17 \\
\hline Fish Meal & 7 & 7 & 6 & 6 \\
\hline Cotton seed Oil & 2 & 2 & 3 & 3 \\
\hline $\mathrm{DCP}$ & 1 & .68 & .7 & .4 \\
\hline Cane Molasses & 5 & 5 & 5 & 5 \\
\hline $\begin{array}{l}\text { Sodium Bentonite } \\
\text { (Filler) }\end{array}$ & 0 & .32 & 0 & .3 \\
\hline Premix\# & + & + & + & + \\
\hline \multicolumn{5}{|l|}{ Nutrients (Formulated) } \\
\hline Dry Matter (DM) & 90.01 & 90.01 & 89.50 & 89.50 \\
\hline Crude Protein (CP) & 23.01 & 23.01 & 20.37 & 20.37 \\
\hline Crude Fibre (CF) & 5.17 & 5.17 & 3.05 & 3.05 \\
\hline Ether Extract (EE) & 3.13 & 3.13 & 4.77 & 4.77 \\
\hline Total Ash & 7.18 & 7.18 & 6.42 & 6.42 \\
\hline Nitrogen Free Extract & 46.58 & 46.28 & 50.23 & 49.95 \\
\hline Calcium (Ca\%) & 1.01 & 0.91 & 0.82 & 0.72 \\
\hline $\begin{array}{l}\text { Total } \\
\text { Phosphorus }(P)\end{array}$ & 0.71 & 0.66 & 0.63 & 0.58 \\
\hline $\mathrm{ME}(\mathrm{Kcal} / \mathrm{Kg})$ & 2948 & 2948 & 3086 & 3086 \\
\hline
\end{tabular}

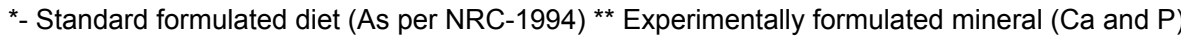
deficient (10\%) diet.

\#*Premix 1) Intermix Regular: 20 g (Vit.A-82500 I.U, Vit. B2-52 mg, Vit. D1-12000 I.U, Vit. K-10 mg, Ca-166 mg, Phosphorus- 395 mg)) 2) Intermix B: $10 \mathrm{~g}$ (Vit B1- 4 mg, Vit. B6-8 mg, Vit. B12-40 microgram, Niacin -60 mg, Calcium Pentothenate- $40 \mathrm{mg}$ ) 3) DOT: $50 \mathrm{~g}$ (Dinitro-o-toulamide- 250mg, ethopabate, $16 \mathrm{mg} / \mathrm{g}$ ) 4) E-Care Se-forte: $25 \mathrm{~g}$ (Vit. E 0.2g and Se 0.04mg/g) 5) Trace Minerals : $100 \mathrm{~g}$ (Ferric Oxide-2 gm, Copper Sulphate-2g, Ferrrous Sulphate-10g, Zinc Sulphate- $0.6 \mathrm{~g}$, Dicalcium Phosphate-53.65 g, Manganese Sulphate- $3 \mathrm{~g}$, Magnesium Sulphate- $25 \mathrm{~g}$, Pottasium iodide- $2.5 \mathrm{~g}$, Sodium thiosulphate- $0.75 \mathrm{~g}$, Zinc Oxide- $1 \mathrm{~g}$ )

Isolated Direct Fed Microbial (DFM): Lactobacillus casei, Streptococcus fecalis were isolated from wild leopard (Panthera leo) feces maintained in 
Dhauladhar Nature park, near Palampur, where as Bakers's yeast (Sacchromyces) was procured locally and characterized by using morphological and biochemical characteristics as proposed by Cowan et al. (1974). Lactobacilli and streptococci were grown in Elliker broth while sacchromyces in Yeast fermentation broth.

Hematology: At 6 weeks of age, approximately $3-5 \mathrm{ml}$ of pooled blood sample of randomly chosen 5 birds per treatment was collected by wing vein puncture, in a sterilized polypropelene centrifuge tube containing EDTA for hematological estimation, and further in sterilized polypropelene centrifuge tubes containing heparin $<0.1$ to $0.2 \mathrm{mg} / \mathrm{mL}$ of blood for the estimation of biochemical parameters. Cholesterol and glucose were estimated by Auto Blood Analyser using analytical kits (Bayer). Data were analyzed statistically (Snedecor and Cochran, 1968).

\section{RESULTS AND DISCUSSION}

The obtained results (Table 2) revealed that average live weight gain and feed conversion during both starter and finisher phase was highest in treatment T1 offered both DFM and standard formulated diet D1, where as live weight gain in DFM supplemented treatment T3 offered experimentally formulated test diet D2 also exhibited higher gain in live weight compared to its control group T2 which was numerically $(8.41 \%)$ higher compared to control T2. Overall broiler growth performance (Table 2) revealed that average gain in live weight and dressing percentage was significantly higher in treatment T1 compared to control T0 where as feed conversion ratio was numerically improved.

Treatment T3 offered experimentally formulated test diet D2 supplemented with isolated DFM also exhibited higher gain in live weight compared to its control T2 but exhibited poor feed conversion ratio. The results are in consonance with the results obtained by Angel et al. (2005) attributing the higher feed conversion ratio to higher food consumption by the birds who gained the most weight during the period resulting from a self-regulatory mechanism or appetite. Kutlu and Forbes (1993a) reported that heat-stressed broiler chicks were able to associate some properties of food with ascorbic acid supplementation and regulated their food intake to match their physiological requirements. It is well documented that dietary ascorbic acid may ameliorate heat-stress related problems in poultry (Kutlu and Forbes, 1993a,b; Zulkifli et al., 1996). In view of this, if DFM supplement is beneficial under stressful conditions, it is likely that, due to post-ingestion feedback, the birds consumed more DFM supplemented diet D2 to match their physiological requirements. It appears that the extra intake did not produce a corresponding increase in body wheight and thus, resulted in a poor food efficiency (Zulkifli et al., 2000). The results revealed that isolated DFM supplementation in treatment T3 improved weight gain suggesting stress-ameliorating effects of the supplement, but at the same time poor food efficiency, as an index of stress response. The results (Table 2) show that treatment T3 was able to match the growth response exhibited by treatment T1 offered standard formulation diet (D1). 

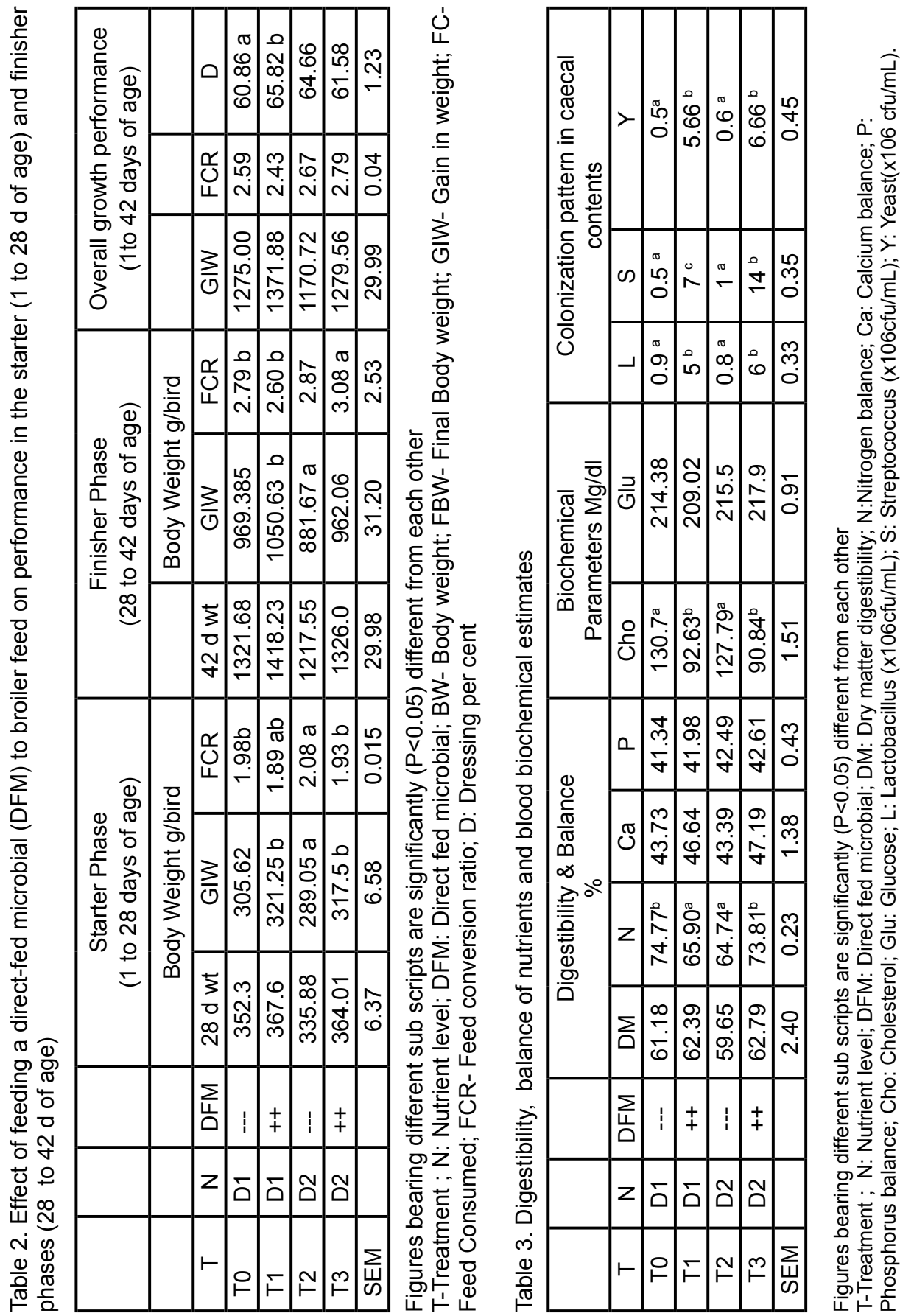
Treatment T1 exhibited significantly higher dressing percent (Table 2) compared to control T0 offered standard diet D1, but the difference was not significant compared to treatments T2 and T3 offered experimentally formulated diet D2. The results were in accordance with the findings of Erdogan (1999) who studied the effect of zinc bacitracin and two different probiotics (Thepax R, Fastrack R) and reported that the dressing percentage was significantly higher in the experimental groups than in the control group.

Digestibility and balance of nutrients (Table 3) revealed that the difference for nitrogen retention in treatments $\mathrm{T} 1$ and $\mathrm{T} 3$ was significant compared to the control group T0. DFM supplemented treatment T3 exhibited 7.33 and 1.16 percent higher calcium retention compared to control T0 and DFM supplemented treatment T1.

Numerically higher calcium retention and better digestibility of dry matter in DFM supplemented treatment T1 offered standard formulated diet D1 may be attributed for better growth of broilers. Similarly, significantly higher nitrogen retention and numerically higher retention of nutrients namely calcium and phosphorus may have played a role in DFM supplemented treatment T3 to combat the negative nutrient stress created when offered experimentally formulated mineral diet D2 exhibiting improved growth performance when compared to T2. The results are not without precedent. Work done with laying hens has shown that the addition of Lactobacillus-based DFM to the diet improves $\mathrm{N}, \mathrm{Ca}$, and $\mathrm{P}$ retention Nahashon et al. (1994, 1996). Angel et al. (2005) reported that nutrient level and DFM affected apparent protein, calcium, and phosphorus retention at 32 or $42 \mathrm{~d}$ of age with retention increasing as nutrient level decreased and with DFM added to the diet. Calcium and phosphorus retention at $28 \mathrm{~d}$ was higher in birds fed DFM (45.8 and $46 \%$, respectively) than in those fed the control diet (38.7 and $40.0 \%$, respectively). Similarly, Li-LiLi et al. (2008) reported that dietary supplementation with the probiotic or the antibiotic consistently improved the ileal digestibility of crude protein and most amino acids in 21- and 42-day-old chickens. An important factor affecting the bioavailability of calcium is the role of oxalic acid, which forms insoluble precipitates, especially calcium oxalate, which lowers its bioavailability. Oxalic acid and oxalates are abundantly present in many plants used as a source of feed for poultry birds. There is some preliminary evidence that the administration of probiotics can affect oxalic acid excretion rates (and presumably oxalic acid levels, as well) Lieske et al. (2005). Tang et al. (2007) reported that fermentation with strains of lactobacillus leads to increased calcium solubility which is related to lowered $\mathrm{pH}$ associated with the production of lactic and acetic acids which in turn enhance calcium bioavailability due to increased calcium solubility. Similar results were published by Angel et al. (2005) who reported that addition of DFM to moderately low nutrient ( $\mathrm{N}, \mathrm{Ca}$ and $\mathrm{P})$ diet overcame the negative effect of nutrient concentration on growth performance.

Higher count of lactobacillus, streptococcus and yeast count was obtained (Table 3 ) in the digestive tract (caecum) of experimental broilers in treatment T1 and T3. The highest lactobacilli count in the digestive tract (caecum) of the 
broilers of treatment T1 and T3 are precisely due to better survival and higher degree of colonization of these microbes, because after hatching of the chicks, lactobacilli are reported to attach to the mucosal lining of the crop during growth and this characteristic avoids their flushing onwards and the attached bacteria inoculate the newly ingested feed. The detached bacteria move with ingesta to the intestine which continue to influence the microbial population resulting in their dominance to compete successfully with the entero pathogens (Fuller, 1986). The microbial colonization pattern revealed higher gram positive to gram negative ratio, coupled with significantly high lactobacillus, streptococcus and yeast count in broilers DFM supplemented (treatment T1 and T3) which contributed to positive intestinal microbial balance. The colonization pattern clearly revealed the ability of supplemented DFM to withstand and resist the acidic secretions and get established in the lower parts of the intestine. These are important attributes of probiotics. Thus, it appears that supplementation of isolated DFM (Table-21) in treatment T1 and T3 had a positive effect on the intestinal microbial balance favoring the establishment of beneficial micro flora in the gastro intestinal tract of the broiler birds. The results are in accordance with the findings of Jin et al. (1996) that the beneficial effect of DFM is by virtue of its ability to maintain a beneficial microflora in the gastro intestinal tract by inhibiting the growth of pathogenic microorganisms Mostafa et al. (2007) reported that the total count of microorganisms increased by increasing the probiotic in the dietary treatment in colon of hens compared with the control group. Further, McLean et al. (2005) while studying the effect of supplementation of Bacillus subtilis on chicken performance concluded that the microflora in the gut appeared to have been beneficially modified (as indicated by spore count recovered from the caecae) and thus had an effect on birds performance.

Lower value of blood cholesterol (Table 3) was found in treatment T3 followed by T1 as compared to the control group T0, and T2. Lowered blood cholesterol in treatment T1 and T3 supplemented with isolated DFM is in agreement with various studies which have reported that lactobacillus can lower the total cholesterol levels and has been suggested to be related to fermentation of indigestible dietary carbohydrates. Further, products of bacterial fermentation, specifically short chain fatty acids, may inhibit cholesterol synthesis in the liver and/or cause the mobilization of blood cholesterol in the liver. The results are in accordance with Kim et al. (2000) who reported significantly lowered blood cholesterol levels in broiler birds supplemented with probiotics. Blood glucose values exhibited no difference amongst treatments indicating no influence of supplementation of DFM on glucose metabolism and was in accordance with the findings of Samanya et al. (2002) who found that in birds, offered B. subtilis, blood glucose concentration was not significantly different among dietary groups. 


\section{CONCLUSION}

It may thus be concluded that supplementation of isolated DFM to broiler birds offered an experimental formulated nutrient ( $\mathrm{Ca}$ and $\mathrm{P}$ ) deficient diet may overcame stress by maintaining a beneficial microflora in the gastrointestinal tract by inhibiting the growth of pathogenic microorganisms and increasing in nutrient utilization through improved intestinal enzyme activities and nutrient availability.

\section{ACKNOWLEDGEMENTS:}

This study was supported by the project of Ministry of Science and Technological Development, No. III 46002 and project Technological Development, 2011-2014, No.031034, Faculty of Agriculture, Novi Sad.

Adress for correspondence:

Prof.dr Shivani Katoch, Assistant Professor

Department of Veterinary and Animal Husbandry Extension,

DGCN COVAS, CSK HPKV, Palampur HP, India

ail: bunnykatoch@yahoo.co.in

\section{REFERENCES}

1. Angel R, Dalloul RA, Doerr J, 2005, Performance of broiler chickens fed diets supplemented with a direct-fed microbial, Poult Scl, 84, 8, 1222-31.

2. AOAC, 1985, Official Methods of Analysis. 14th Ed. Association of Official Analytical chemists, Arlington, Virginia.

3. Apata $D F, 2008$, Growth performance, nutrient digestibility and immune response of broiler chicks fed diets supplemented with a culture of Lactobacillus bulgaricus. J Sci Food Agricult, 88, 7, 1253-8.

4. Baba E, Nagaishi S, Fukata T and Arakawa A, 1991, The role of intestinal microflora on the prevention of Salmonella colonization in gnotobiotic chickens. Poult Sci, 70, 1902-7.

5. BIS, 1992, Poultry feeds specifications. Bureau of Indian standards. Manak Bhawan, 9 Bahadurshah Zafar marg, New-Delhi.

6. Cowan ST, Holt J, Liston J, Murray RGE, Nivin CF, Ravin AW et al., 1974, "Bergey's Manual of Determinative Bacteriology". 8th Ed.

7. Erdogan Z, 1999, The using of antibiotic and probiotic in broiler diets (Broyler rasyonlarinda antibiyotik ve probiyotik kullanilmasi), Lalahan Hay, Arast Enst Derg, 2, 57-69.

8. Fuller R, 1986, Probiotics, J Appl Bacteriol, Symposium supplement. 15-75.

9. Isolauri E, Jantenen M, Rautanen T, Sillanaukee $P$, Koivala T, 1991, A human lactobacillus strain promotes recovery from acute diarrhea, Pediatrics, 88, 90-97.

10. Jin LZ, Ho YW, Abdullah N Jalaludin S, 1996, Influence of dried Bacillus subtilis and lactobacilli cultures on intestinal microflora and performance in broilers, Asian-Australas, J Anim Sci, 9, 397-404.

11. Kim YR, Ahn K, Kim S, Kang CW, 2000, Effects of dietary supplementation of probiotics (MS102Reg.) on performance, blood cholesterol level, size of small intestine and intestinal microflora in broiler chicks, Kor J Anim Sci, 42 ,6, 849-58.

12. Kutlu HR, Forbes JM, 1993a, Self-selection of ascorbic acid in coloured foods by heat-stressed broiler chicks, Physiol Beh. 53, 103-10.

13. Kutlu HR, Forbes JM, 1993b, Changes in growth and blood parameters in heat-stressed broiler chicks in response to dietary ascorbic acid, Livest Prod Sci, 36, 335-50.

14. Lyons TP, 1987, The role of biological tools in the feed industry, In: TP. Lyons (Ed.). Biotechnology in the feed industry. Altech Technical Publications, Nicholasville, Kentucky, 1-50. 
15. Li LiLi, Hou Zheng Ping, Li Tie Jun, Wu Guo Yao, Huang Rui Lin, Tang Zheng Ruan, Yang Cheng Bo, et al., 2008, Effects of dietary probiotic where s supplementation on ileal digestibility of nutrients and growth performance in 1-to 42-day-old broilers, J Sci Food Agricult, 88, $135-42$.

16. Lieske JC, Goldfarb DS, De Simone C, Regnier C, 2005, Use of a probiotic to decrease enteric hyperoxaluria, Kidney Int, 68, 3, 1244-9. doi:10.1111/j.1523-1755.2005.00520.x. PMID 16105057.

17. Mostafa KEME, Roushdy KH, 2007, The effect of genotype, lactic acid bacteria and their interaction on performance of two local layer hens, Egypt Poult Sci J, 27, 1, 165-83.

18. McLean J, Acamovic T, Hansen S, Moerk Jensen M and Nevison I, 2005, Benefits of Bacillus subtilis supplementation in chicken diets, Proceedings of the 15th European Symposium on poultry nutrition, Balatonfured, Hungary, 25-29 September, 388-90.

19. Nahashon SN, Nakaue HS, Mirosh LW, 1994, Production variables and nutrient retention in Single Comb White Leghorn laying pullets fed diets supplemented with direct fed microbials, Poult Sci, 73, 1699-1.

20. Nahashon SN, Nakaue HS, Mirosh LW,,1996, Nutrient retention and production parameters of Single Comb White Leghorn layers fed diets with varying crude protein levels and supplemented with direct-fed microbials, Anim Feed Sci Technol, 61, 17-26.

21. National Research Council, 1994, Nutrient Requirements of Poultry. 9th rev. ed. National Academy Press, Washington, DC.

22. Parks PE, Dunn DE, 1963, Evaluation of the molybovanadate photometric determination of phosphorus in mixed feeds and mineral supplements, J Agricult Chem, 46, 836-42.

23. Shahani KM, Vakil JR, Kilar Mi, 1971, Natural activity of Lactobacillus acidophilus and bulgaricus, Cult Dairy Prod J, 11, 2, 14-7.

24. Smith HW, 1965, The development of the flora of alimentary tract in young animals, $J$ Pathol Bacteriol, 90, 495.

25. Snedecor GW, Cochran WG, 1968, Statistical Methods, 6th Edition. Oxford and ING Publ Co, Calcutta.

26. Samanya M, Yamauchi K, 2002, Comparative Biochemistry and Physiology, A Molecular and Integrative Physiology, 133, 1, 95-104. 46 ref.

27. Suskovic J, Brkic $B$ and Matosic S, 1997, Mechanism of probiotic activity of lactic acid bacteria, Mijekarstvo, 47, 1, 57-73.

28. Sanders ME, 1984, Benefits of feeding probiotics, Food technol, $53,11,:$ 67-77.

29. Sitonen S, Vapaatalo H, Salminen S, Gordin, A, Saxelin, M, Wikberg $R$ et al., 1990, Effect of lactobacillus GG yogurt in prevention of antibiotic associated diarrhea, Ann Med, 22, 57-9.

30. Seki M, Lgarashi T, Fukuda Y, Simamura S, Kaswashima T, Ogasa K, 1978, The effect of bifidobacterium cultured milk on the regularity among an aged group, Nutr Food Stuff, 31, 3, 79-87.

31. Tang A L, Shah N P, Wilcox G, Walker K Z, Stojanovska L, 2007, Fermentation of calciumfortified soymilk with Lactobacillus: effects on calcium solubility, isoflavone conversion, and production of organic acids, J Food Sci, 72, 9, M431-M436.

32. Topping $D L$, 1996, Short chain fatty acids produced by intestinal bacteria, Asia Pacific $J$ Clin Nutr, 5, 1, 15-9.

33. Vicente J L, Avina L, Torres Rodriguez A, Hargis B,Tellez G, 2007, Effect of a Lactobacillus spp-based probiotic culture product on broiler chicks performance under commercial conditions, Int J Poult Sci, 6, 3, 154-6.

34. Zulkifli I, Ramlah AH, Vidyadaran MK, Rasedee A, 1996, Dietary ascorbic acid: Self-selection and response to high temperature and humidity in broilers, Malaysian Appl Biol, 25, 93101.

35. Zulkifli I,Abdullah N, Mohd N, Azrin Y, Ho W, 2000, Growth performance and immune response of two commercial broiler strains fed diets containing Lactobacillus cultures and oxytetracycline under heat stress conditions, Brit Poult Sci, 41, 5, 593-7. 


\section{PROIZVODNE KARAKTERISTIKE BROJLERA HRANJENIH OBROCIMA RAZLIČITE HRANLJIVE VREDNOSTI SA DODATIM PROBIOTIKOM}

KATOCH S, SHARMA KA, CHAHOTA R, SHARMA KS, MARKOVIĆ RADMILA i ŠEFER D

\section{SADRŽAJ}

Ispitivan je uporedni odgovor na različite izolovane sojeve (Direktna ishrana mikrobima-DFM) laktobacila, streptokoka i kvasaca izolovanih iz izmeta leoparda (Panthera leo) upotrebljenih kao probiotik u ishrani živine sa različitom količinom mineralnih materija, kalcijuma i fosfora. Različite tretmane su činili T0 (Kontrola, medijum) i T1 (Lactobacillus casei + Streptococcus fecalis + Saccharomices cerevisiae) koji su dobijali standardno formulisan obrok D1, T2-Kontrola (medijum) sa 10\% manje kalcijuma i fosfora - obrok D2, T3 (Lactobacillus casei + Streptococcus fecalis + Saccharomices cerevisiae) sa deset odsto manje kalcijuma i fosfora - obrok D2. Proizvodni rezultati, dobijeni tokom starter faze (od 1. do 3. nedelje), pokazuju veći prirast u živoj telesnoj masi i nižu konverziju hrane kod oba tretmana sa dodatim DFM, T1 sa standardno formulisanim obrokom D1 i tretmana T3 sa eksperimentalno formulisanim sastavom minerala (Ca i P) umanjenim za 10\% - obrok D2 u odnosu na odgovarajuće kontrole T0 i T2. Ukupno dobijeni rezultati pokazuju značajno veći prirast kod T1 tretmana u odnosu na njegovu kontrolu T0 kao i numerički veći prirast u tretmanu T3 sa eksperimentalno formulisanim sastavom minerala ( $\mathrm{Ca}$ i P) umanjenim za $10 \%$ - obrok D2 sa dodatkom izolovanih DFM u poređenju sa njegovom kontrolom T2. Ogledne grupe T1 i T3 sa dodatkom izolovanih DFM su pokazale bolju ravnotežu u pogledu crevne mikroflore, efikasnu kolonizaciju i veći broj u crevima sa numerički većom retencijom kalcijuma i fosfora prilikom ispitivanja svarljivosti. Dakle, utvrđeno je da dodatak izolovane DFM ima potencijal da poboljša proizvodne rezultate živine pri upotrebi standardno formulisanog obroka D1 kao i obroka D2 sa deficitom minerala. 